\title{
Incidence of hemoglobinopathies in Northwest Paraná, Brazil
}

\section{Incidência de hemoglobinopatias no noroeste do Paraná - Brasil}

Flavio A. V. Seixas

Cíntia D. Silva

Jane Tominaga

Octávia C. Ferro

Luana G. Nilson

\begin{abstract}
Immigrants from many parts of the world settled in Paraná State in Brazil, contributing to the diversified genetic patrimony of its population. This characteristic led us to investigate, for the first time, the incidence of hemoglobinopathies in the population of one city in Paraná. A total of 585 blood samples were collected from individuals living in Umuarama. Hemoglobinopathy tests were carried out using the classical methodology. The results show that $93.17 \%$ have the normal electrophoretic pattern (AA); $2.73 \%$ have the beta-thalassemia trait; $2.05 \%$ have the sickle cell trait $(A S) ; 1.37 \%$ are heterozygous for alpha-thalassemia; $0.34 \%$ heterozygous for hemoglobin $C(A C)$; $0.17 \%$ have both alpha-thalassemia and sickle cell traits and $0.17 \%$ are heterozygous for alpha and beta-thalassemia. A comparison of these results with other works suggests that the frequency of hemoglobinopathies can significantly vary between cities within the same state. This fact may be attributed to the miscegenation of the population or even to the diverse prevalence of hemoglobinopathies in distinct populations. Rev. bras. hematol. hemoter. 2008;30(4):287-291.
\end{abstract}

Key words: Hemoglobinopathies; incidence; electrophoresis; sickle cell trait.

\section{Introduction}

The study of hemoglobinopathies is a subject of growing interest among Brazilian researchers and health authorities, as different studies have shown that these genetic diseases are a national public health problem. ${ }^{1-3} \mathrm{~A}$ reflection of this concern is the decree of June 6, $2001\left(\mathrm{n}^{\circ}\right.$ 822) of the Brazilian Health Ministry that requires hemoglobinopathy screening of newborn babies using the well-known Guthrie test.

Despite of this move forward in terms of public health, some hematological disorders such as the alpha and betathalassemia traits are not detected with this screening, as the method adopted for testing is based on the identification and measurement of hemoglobins, such as $\mathrm{Hb} \mathrm{A}^{2}$, that are revealed in adults ${ }^{4}$ thus, in newborn babies, this marker is masked by the relatively high quantity of fetal haemoglobin. ${ }^{5}$

For these reasons, individuals with the beta-thalassemia trait may grow up without knowing about their condition and without the possibility of familiar planning for couples with this trait. These individuals may also suffer from mild anemia which, in many cases, is confused with iron deficiency ane- mia and hence patients receive inappropriate treatment. Thus, an investigation of the incidence of hemoglobinopathies in the Brazilian population is justified.

It is well know that the ethnic composition of the population contributes to the distinct prevalences of these diseases in each region. Paraná State in Brazil has a heterogeneous population, formed by the descendants of many ethnic groups including Poles, Portuguese, Italians, Germans, Ukrainians, Dutch, Spanish, Japanese, Arabs, Indians and Negroes. ${ }^{6}$ Paraná State also has a genetic diversity resulting from miscegenation and, despite of this, there are no published works about the incidence of hemoglobinopathies. This work is, therefore, the first carried out in the state with the objective of investigating and reporting the prevalence of hemoglobinopathies of the population in one city.

\section{Material and Methods}

Blood samples were collected from patients attended in the services of the Clinical Analysis Laboratory (LAC) at Unipar with requests for blood tests. For this procedure, blood

Instituto de Ciências Médicas e Biológicas - Universidade Paranaense (Unipar) - Umuarama-PR.

Correspondence: Flavio A. V. Seixas

Rua Paraíba, $n^{\circ} 5182$ - Zona 2

87508-390 - Umuarama-PR - Brasil

E-mail: flavio.seixas@unipar.br 
was drawn by venous puncture using EDTA as anticoagulant. After collection, the aims of the study were presented to patients and their informed written consent was obtained. Samples were collected once a week on alternative Mondays and Tuesdays, in the period from April 2005 to May 2006. Information, including name, address, age, gender, profession, use of medications and family cases of anemia, was obtained by means of an interview. The individuals were classified as Caucasoid, Negroid, mulatto, Asian or Indian, in respect to phenotypic characteristics, such as the color of the skin and eyes, lip and nose shape and characteristics of the hair.

In the initial examination, samples were analyzed using the methodology described by $\mathrm{LHGDH},{ }^{7}$ first by the resistance to hypotonic shock test in a $0.36 \% \mathrm{NaCl}$ solution, followed by an investigation of $\mathrm{Hb} \mathrm{H}$ in red blood cells after staining with brilliant blue cresyl, careful analysis of the red blood cell morphology from fresh blood and also by electrophoresis at $\mathrm{pH} 8.5$ of hemolysed whole blood prepared with $1 \%$ saponin applied to cellulose acetate. Measurement of $\mathrm{Hb}$ fractions was carried out by electrophoresis of $20 \mu \mathrm{L}$ of hemolysed blood on cellulose acetate under the aforementioned conditions. After separation, measurement of $\mathrm{Hb} \mathrm{A}_{2}$ was achieved by water elution, followed by absorbance readings in a digital spectrophotometer at $415 \mathrm{~nm}$. Samples that demonstrated variant fractions in alkaline electrophoresis were confirmed by acid electrophoresis at pH 6.2 using agar phosphate gel. The hematological parameters (MGH, GV, MGHC and hematocrit) were determined using a Cell-Dyn 1400 apparatus. Cases that were positive for any hemoglobinopathies were referred for free consultations with a general physician or a pediatrician in the Health School Centre in the city.

The Epi Info computer program version $6,{ }^{8}$ utilized to calculate the necessary sample size, demonstrated that 573 samples were necessary for achieve a reliable index of $95 \%$ with a possible experimental error of $5 \%$ in a population of approximately 95,000 inhabitants.

\section{Ethical considerations}

This work was carried out after approval from the Research Ethics Committee of Unipar and followed the ethical principles established by the resolution 196/96 of the National Health Council - Conep, as well the ethical principles of Helsinki declaration of 1964 as revised in 2000 by the World Medical Association. Each participant gave their informed written consent.

\section{Results}

For this work, 585 blood samples were collected from individuals aged between 1 and 72 years old and pertaining to different ethnic groups with a predomination of European descendants $(78.8 \%)$. The general characteristics of the population are summarized in Table 1 which shows a threefold higher participation of women compared to men. The results showed that 40 individuals $(6.84 \%)$ were heterozygous for at least one type of hemoglobinopathy while 545 individuals (93.16\%) did not present hematological alterations. No homozygous individuals for any type of hemoglobinopathy were found.

The results of the different phenotypes identified in this research are shown in Table 2, where they are classified by gender and ethnic group.

Of the forty patients $(100 \%)$ identified as carriers of hemoglobinopathies, thirty-five $(87.5 \%)$ did not have prior knowledge of their condition and two (5.0\%) were undergoing ferrous sulfate-based treatment for iron deficiency anemia. Five of these forty patients (12.5\%) knew they were carriers with only one (2.5\%) being treated regularly with folic acid.

The results showed that heterozygous betathalassemia was the most frequent hemoglobinopathy in the population of Umuarama corresponding to $2.73 \%$ of the samples analyzed. The main marker used in the diagnosis of this hemoglobinopathy was the increase of hemoglobin $\mathrm{A}_{2}{ }^{5,9,10} \mathrm{It}$ is well known that increased concentrations of hemoglobin $\mathrm{A}_{2}$, can also be associated with other acquired or congenital factors other than the beta-thalassemia trait. ${ }^{11}$ Temporarily increased levels of this hemoglobin fraction have already been described in hyperthyroidism, malaria and megaloblastic anaemia. ${ }^{12}$ Taking this possibility into consideration, patients were asked in a specific interview about these diseases and also if they were under treatment at the time of collection.

On the other hand, the presence of the beta-thalassemia trait is not always associated to an increase in $\mathrm{Hb} \mathrm{A}_{2}{ }^{10,13}$ and thus complementary tests to detect the beta-thalassemia trait are justified. Recent research has pointed to possible molecular methods to identify this hemoglobinopathy in the future. $^{14}$

Table 1. General characteristics of analyzed population

\begin{tabular}{lcc}
\hline Gender & $\mathrm{n}$ & $\%$ \\
Male & 161 & 27.52 \\
Female & 424 & 72.48 \\
Total & 585 & 100.00 \\
\hline Ethnic group & $\mathrm{n}$ & $\%$ \\
$\quad$ European descendants & 461 & 78.80 \\
$\quad$ African descendants & 88 & 15.05 \\
Brown people & 17 & 2.90 \\
Asiatic descendants & 11 & 1.88 \\
Indians and descendants & 08 & 1.37 \\
Total & 585 & 100.00 \\
\hline Did carriers know about their disease & & \\
before participation in this work? & $\mathrm{n}$ & \\
Yes & 05 & 12.5 \\
Not & 35 & 87.5 \\
Total & 40 & $100 \%$ \\
\hline
\end{tabular}


Table 2. Phenotypic distribution of hemoglobinopathies by ethnic group and gender

\begin{tabular}{|c|c|c|c|c|c|c|c|}
\hline \multirow{2}{*}{ Ethnic group } & \multicolumn{7}{|c|}{ Phenotype } \\
\hline & AA & $\beta$-thal trait & AS & $\alpha$-thal trait & $A C$ & $\alpha$-thal / $\beta$-thal & AS / $\alpha$-thal \\
\hline European descendants & $430(73.51)$ & $14(2.39)$ & $07(1.20)$ & $07(1.20)$ & $02(0.34)$ & $01(0.17)$ & - \\
\hline African descendants * & $96(16.41)$ & $02(0.34)$ & $05(0.85)$ & $01(0.17)$ & - & - & $01(0.17)$ \\
\hline Asiatic descendants & $11(1.88)$ & - & - & - & - & - & - \\
\hline Indians and descendants & $08(1.37)$ & - & - & - & - & - & - \\
\hline Total & $545(93.17)$ & $16(2.73)$ & $12(2.05)$ & $08(1.37)$ & $02(0.34)$ & $01(0.17)$ & $01(0.17)$ \\
\hline \multicolumn{8}{|l|}{ Gender } \\
\hline Male & $140(25.70)$ & $8(50.0)$ & $6(50.0)$ & $4(50.0)$ & $2(100.0)$ & $1(100.0)$ & - \\
\hline Female & $405(74.31)$ & $8(50.0)$ & $6(50.0)$ & $4(50.0)$ & - & - & $1(100.0)$ \\
\hline Total & $545(100 \%)$ & $16(100 \%)$ & $12(100 \%)$ & $8(100 \%)$ & $2(100 \%)$ & $1(100 \%)$ & $1(100 \%)$ \\
\hline
\end{tabular}

* Include black and brown people

The second most frequent hemoglobinopathy was the sickle cell trait $(2.05 \%)$, followed by heterozygous alphathalassemia (1.37\%) and finally the $\mathrm{Hb} C$ trait $(0.34 \%)$. In the case of the sickle cell and $\mathrm{Hb} \mathrm{C}$ traits, the main techniques used for diagnosis were electrophoresis in alkaline and acid $\mathrm{pH}$ with consecutive measurements of the $\mathrm{Hb}$ fractions. In relation to heterozygous alpha-thalassemia, only patients who presented concomitantly a visible fraction of $\mathrm{Hb} \mathrm{H}$ in alkaline electrophoresis, precipitations of $\mathrm{Hb} \mathrm{H}$ after staining and alterations in the blood test were considered carriers, thereby providing diagnostic reliability. Eight samples (1.37\%) were positive for all these markers, fewer than electrophoretical test in isolation have shown.

Hemoglobinopathy associations were also identified in patients. One of them presented an interaction between heterozygous alpha and beta thalassemias with confirmation being achieved by a study of parents (the mother was a carrier of alpha-thalassemia and the father of beta-thalassemia) and also the son (a beta-thalassemia carrier).

Another patient presented an association between sickle cell and alpha-thalassemia trait, which was identified through a measurement of $\mathrm{Hb}$ fractions and the blood test. In this case, it was not possible to carry out a family study because the patient was not interested and resisted any investigation.

\section{Discussion}

The distribution of hemoglobinopathies relates to the different racial groups that participated in the formation of the Brazilian population. ${ }^{5}$ Thalassemias affect Asian and European descendants more frequently, hence these diseases are more frequent in regions that have greater colonization by these groups, in particular, by Italians. ${ }^{9}$

According to historical data from the Umuarama city hall about foreign immigrants that colonized the region, $60 \%$ were Italians, $20 \%$ Portuguese, $15 \%$ Japanese and $5 \%$ from other nations. ${ }^{15}$ The result of this migration is very evident when the distribution of the population in Umuarama city by ethnic group is analyzed, as presented in Table 3.

The higher frequency of heterozygous betathalassemia compared to other hemoglobinopathies found in the population of Umuarama may be justified by the ethnic origins of the population, as most of the inhabitants are descendants of Italians, a nation very commonly affected by thalassemia. ${ }^{16-20}$ As Paraná state was influenced by migration of people from São Paulo, in the north, and from Rio Grande do Sul and Santa Catarina States, in the south, ${ }^{21}$ theoretically the incidence of hemoglobinopathies was also influenced by these two regions. Comparing the incidence of heterozygous beta-thalassemia of $2.73 \%$ found in our results with works carried out by other authors in the southern region of Brazil, we found an incidence of $9.87 \%$ among blood donors in Caxias do Sul, ${ }^{9}$ while in Porto Alegre, the incidence of this trait in the Caucasian population was only $1.10 \% .^{22}$

On the other hand, in São Paulo State, results of studies of blood donors in São José do Rio Preto showed that the incidence of heterozygous beta-thalassemia was $8.92 \%{ }^{23}$ and in the student population in Bragança Paulista, the incidence was only $1.2 \% .^{3}$

The different incidences showed in these four works suggests that the distribution of the beta-thalassemia trait is not homogeneous for cities in the same state or perhaps that these divergences are only a reflection of specific prevalences in differentiated populations such as blood donors, students, newborn babies or patients with anemia as these were the target populations of the different studies.

Some studies targeted blood donors ${ }^{23-24}$ thereby excluding, due to the selective interview utilized, individuals with anemia. In our work we did not exclude any type of patient, thus guaranteeing a more realistic scenario of the incidence of these diseases. Based on published works about the incidence of hemoglobinopathies in cities throughout the country, it is possible to see the frequency 
Table 3. Distribution of Umuarama population by ethnic group

\begin{tabular}{ccccc}
\hline Ethnic group & Male & Female & Total & $\%$ \\
\hline Caucasians & 32,939 & 36,011 & 68.950 & 76.03 \\
Brown people & 8,665 & 8,254 & 16.919 & 18.66 \\
Black & 1,570 & 1,159 & 2.729 & 3.01 \\
Asiatic & 932 & 627 & 1.559 & 1.72 \\
Indians & 51 & 78 & 129 & 0.14 \\
Without declaration & 191 & 212 & 403 & 0.44 \\
\hline Total & 44,348 & 46,341 & 90,689 & 100.0
\end{tabular}

Source: IBGE demographic census 2000

Table 4. Distribution of hemoglobinopathies (\%) in different cities of Brazil listed from south to north by state

\begin{tabular}{cccccccccc}
\hline & $\mathrm{RS}^{9}$ & $\mathrm{PR}$ & $\mathrm{SP}^{3}$ & $\mathrm{SP}^{23}$ & $\mathrm{SP}^{25}$ & $\mathrm{RJ}^{26}$ & $\mathrm{MG}^{24}$ & $\mathrm{BA}^{27}$ & $\mathrm{RN}^{28}$ \\
\hline Normal pattern (AA) & 88.32 & 93.17 & - & 95.04 & - & 95.26 & - & 82.62 & - \\
$\beta$-thalassemia trait & 9.87 & 2.73 & 1.2 & 0.38 & 0.8 & 0.27 & 0.13 & - & - \\
$\alpha$-thalassemia trait & 0.66 & 1.37 & - & 1.90 & - & 0.55 & - & - & - \\
$\mathrm{AS}$ & 0.99 & 2.05 & 0.6 & 0.76 & 1.2 & 3.24 & 2.48 & 9.81 & 2.22 \\
AC & 0.16 & 0.34 & 0.2 & 1.14 & 0.5 & 0.41 & 0.73 & 6.54 & 0.16 \\
Others ** & - & 0.34 & - & 0.76 & - & 0.27 & 0.08 & 1.03 & - \\
Sampling (n) & 608 & 585 & 1,118 & 264 & 599 & 2,190 & 23,981 & 581 & 630 \\
\hline
\end{tabular}

** other Hbs and/or interactions; - not found or not mentioned

of traits of these diseases in the Brazilian population. Table 4 illustrates the results of published studies on some Brazilian cities, categorized by state from south to north. There is a clear decrease in the incidence of thalassemias and increase in the incidence of hemoglobins $\mathrm{S}$ and $\mathrm{C}$ from the south to the north.

In respect to alpha-thalassemia, different methodologies used in the analysis of this hemoglobinopathy and the uneven distribution of the Brazilian population, are factors that make determination of its true frequency difficult.

At the moment, diagnosis is achieved by molecular analysis using the PCR technique. ${ }^{29-30}$ The classical methodology used in our study is not able to detect all carriers and, because of this, the frequency of alphathalassemia found in this and in some other works may be even higher. This is because carriers with only one defective alpha gene $(-\alpha / \alpha \alpha)$, may not exhibit phenotypic alterations at sufficient levels to be detected by the methodology employed in this study due to the compensatory character of the expression of healthy alpha genes. ${ }^{31}$ Studies have shown a great variability in the proportion of individuals with alphathalassemia in Brazil and throughout the world. ${ }^{32}$

In relation to variant hemoglobins, only $\mathrm{Hb} \mathrm{S}$ and $\mathrm{Hb} \mathrm{C}$ were found in the heterozygous form. The incidences of these two hemoglobins were not different to our expectations; therefore, the fact that the Caucasian population presented a higher incidence of these traits compared to the afrodescendent population surprised us. This may be explained by the historical flow of genes between these two races in Brazil. This has already been observed by other authors ${ }^{9,33}$ and so the real significance of this scenario in preventive medicine remains unclear. Concerning this, our results show that, at least in Umuarama, the sickle cell trait should not be confused with a pathology that mainly affects Negroid individuals thereby serving as a warning to physicians, in order to prevent incorrect therapies in Caucasian $\mathrm{Hb} \mathrm{S}$ and $\mathrm{Hb} \mathrm{C}$ carriers.

Despite of the incidence of the sickle cell trait in this work being a little higher than those found in the populations of Rio Grande do Sul ${ }^{22}$ and Sao Paulo ${ }^{23}$ this difference may be, in part, explained by the fact that the target populations of these two works were blood donors. Individuals are tested for the sickle cell trait before being accepted as blood donors and consequently excluded, a fact that over time decreases the frequency of these individuals in blood banks. Tests for the thalassemia trait are not routine in the selection of blood donors, and as a consequence, individuals may return for further donations if they do not present anemia at a level sufficient for exclusion.

Based on our results, we conclude that the population of Umuarama presents with the most common hemoglobinopathies in Brazil, at an expected frequency compatible with the colonization of the city. We also concluded that $\mathrm{Hb} \mathrm{S}$ and $\mathrm{Hb} \mathrm{C}$ are more common in Caucasians than in African descendants. This factor must be taken into consideration by physicians and by public health programs when establishing preventive policies for hemoglobinopathies in this region.

The knowledge of carriers about their origins and the physiological consequences of hemoglobinopathies, as well as the indexes of these diseases observed in the population from Umuarama, suggests that education campaigns are necessary for the population and local health professionals.

\section{Resumo}

O estado do Paraná, no Brasil, recebeu imigrantes de diversas partes do mundo. Este fato atribuiu à sua população um patrimônio genético bastante diversificado. Esta característica nos levou a investigar, pela primeira vez, a incidencia de hemoglobinopatias na população que vive em uma de suas cidades. Para isso, foram coletadas amostras de sangue de 585 pessoas residentes em Umuarama-PR. A triagem para hemoglobinopatias foi realizada através da metodologia clássica. Os resultados mostraram que 93,17\% apresentaram o padrão eletroforético normal (AA); 2,73\% apresentaram o traço beta-talassêmico; 2,05\% o traço falciforme (AS); 1,37\% heterozigotos para alfa-talassemia; $0,34 \%$ 
heterozigotos para hemoglobina $C$ (AC); 0,17\% tiveram a associação entre alfa talassemia e traço falciforme e também $0,17 \%$ tiveram a associação entre os traços alfa e beta talassêmicos. A comparação destes resultados com o de outros autores sugere que a freqüencia das hemoglobinopatias pode variar significativamente dentro de cidades de um mesmo estado. Este fato pode ser atribuído à miscigenação da população ou também à prevalência distinta de hemoglobinopatias em populações diferenciadas, que foram o alvo de outros estudos. Rev. bras. hematol. hemoter. 2008;30(4):287-291.

Palavras-chave: Hemoglobinopatias; incidencia; eletroforese; traçofalciforme.

\section{Acknowledgements}

We would like to thanks to Unipar by the financial support. We also thank to the staff from Laboratory of Clinical Analysis of Unipar, in special to Dr. Francisco Matumoto by their collaboration; Dr. Erildo Müller and the college students Adriana Tiemi Itikawa and Clarissa Manchini.

\section{References}

1. Ramalho AS, Magna LA, de Paiva-e-Silva RB. Government directive MS \# 822/01: unique aspects of hemoglobinopathies for public health in Brazil. Cad Saude Publica. 2003;19(4):1195-9.

2. Oliveira F. Saúde da população negra. Brasília: OPAS, 2002.

3. Compri MB, Polimeno NC, Stella MB, Ramalho AS. Public health programs for hereditary hemoglobinopathies in high school students in Brazil. Cad. Saúde Pública. 1996;30(2):187-95.

4. Brasil. Ministério da Saúde: Manual de normas técnicas e rotinas operacionais do programa nacional de triagem neonatal. Série A. Normas e Manuais Técnicos. Brasília: 2002.

5. Naoum PC. Hemoglobinas e Talassemias. São Paulo: Sarvier, 1997.

6. Governo do Estado do Paraná: Pessoas, família e sociedade. http:/ /www.pr.gov.br (acessado em 09/Jan/2007).

7. Lhgdh. Protocolos de metodologias laboratoriais clássicas para o diagnóstico de hemoglobinopatia. http://www.lhgdh.locaweb.com.br (acessado em 05/Abr/2005)

8. CDC - Centers for Disease Control and Prevention. Epi Info, version 6.0. http://www.cdc.gov/EpiInfo/ (acessado em 05/Abril/2005).

9. Lisot CL, Silla LM. Screening for hemoglobinopathies in blood donors from Caxias do Sul, Rio Grande do Sul, Brazil: prevalence in an Italian colony. Cad Saude Publica. 2004;20(6):1595-601.

10. Madan N, Sikka M, Sharma S, Rusia U. Haematological parameters and $\mathrm{HbA}_{2}$ levels in beta-thalassemia trait with coincident iron deficiency. Indian J Pathol Microbiol. 1998;41(3):309-13.

11. Gasperini D, Cao A, Paderi L, Barella S, Paglietti E, Perseu L et al. Normal individuals with high $\mathrm{Hb} \mathrm{A}_{2}$ levels. Br J Haematol. 1993; 84(1):166-8.

12. Willcox M, Brohult J, Sirleaf V, Bengtsson E. Malaria and haemoglobin $\mathrm{A}_{2}$ levels in northern Liberia. Trans R Soc Trop Med Hyg. 1979;73(2):209-11.

13. Fortová H, Slavíková V, Musil F, Suttnar J, Brabec V. Diagnosis of beta-thalassemia on the basis of $\mathrm{Hb} \mathrm{A}_{2}$ determination. Vnitr Lek. 1995;41(5):302-6

14. Oliveira TM, Souza FP, Jardim AC, Cordeiro JA, Pinho JR, Sitnik $\mathrm{R}$ et al. HFE gene mutations in Brazilian thalassemic patients. Braz J Med Biol Res. 2006;39(12):1575-80.

15. Prefeitura Municipal de Umuarama: História. http://www. umuarama.com.br (acessado em 18/Nov/2005).
16. Tentori L, Marinucci M, Massa A, Giuliani A, Mavilio F. Hemoglobinopathies in Italy: Geographic distribution and criteria for their screening. Recenti Prog Med. 1981;71(2):148-69.

17. Giampaolo A, Mavilio F, Massa A, Gabbianelli M, Guerriero R, Sposi NM et al. Molecular heterogeneity of beta thalassaemia in the Italian population. Br J Haematol. 1984;56(1):79-85.

18. Maffei L, Foglietta E, Cappabianca MP, Lerone M, Mastropietro F, Bianco I. The prevention of the thalassemia maior: emergent problems. Haematologica. 2002;87(12):ELT44.

19. Sarti F, Cesaro S, Sanvitale G, Tisato A, Petris MG, Zanesco L. Prevalence of heterozygosity for beta-thalassemia among intermediate lower school children in an area of the Venetian lacuna. Pediatr Med Chir. 1992;14(6):609-10.

20. Vardeu F. Epistemology and $\beta$-thalassemia. Med Secoli. 2005; 17(1):123-8

21. Rigotti JIR. Geografia dos fluxos populacionais segundo níveis de escolaridade dos migrantes. Estudos Avançados 2006;20(57):237254.

22. Freitas EM, Rocha FJ. Detection of beta-thalassemia heterozygotes among caucasians from Porto Alegre, RS, Brazil. Rev Bras Genet. 1983;6(1):185-188.

23. Orlando GM, Naoum PC, Siqueira FAM, Bonini-Domingos CR. Laboratory diagnosis of hemoglobinopathies in different population groups. Rev Bras Hematol Hemoter. 2000;22(2):111-121.

24. Melo SMA, Arantes SCF, Botelho-Filho A, Rocha AFS. Prevalência de hemoglobinopatias em doadores de sangue do hemocentro regional de Uberlândia-MG. Rev Bras Hematol Hemoter. 2000;22, supl. 51.

25. Moreira, HW, Naoum PC, Ferreira RR, Fonseca LM, Mendonça, $\mathrm{CP}$, Arantes JB et al. Distribution of hemoglobins phenotypes in Vale do Ribeira, São Paulo. Rev Bras Patol Clin. 1989;25(3):76-9.

26. Silva-Filho I, Gonçalves MS, Adôrno EV, Campos DP, Fleury MK. Screening of abnormal haemoglobin and the evaluation of oxidative degeneration of haemoglobin among workers with the sickle cell trait (HbAS), exposed to occupational hazards. Rev Bras Hematol Hemoter. 2005;27(3):183-187.

27. Adorno EV, Couto FD, Moura Neto JP, Menezes JF, Rêgo M, Reis MG et al. Hemoglobinopathies in newborns from Salvador, Bahia, Northeast Brazil. Cad Saude Publica. 2005;21(1):292-8.

28. Bezerra TM, Andrade SR. Investigação sobre a prevalência de hemoglobinas anormais entre doadores de sangue. Rev Bras Anal Clin 1991;23(4):117-8

29. Cançado RD. Alpha thalassemia. Rev Bras Hematol Hemoter 2006; 28(2):81-87.

30. Zamaro PJA, Melo LS, Mendiburu CV, Bonini-Domingos CR. Alfa talassemia: metodologia clássica ou estudo molecular? Rev Bras Anal Clin 2006;38:(suplemento)46B.

31. Higgs DR, Garrick D, Anguita E, De Gobbi M, Hughes J, Muers M et al. Understanding alpha-globin gene regulation: Aiming to improve the management of thalassemia. Ann N Y Acad Sci. 2005; 1054:92-102.

32. Vichinsky EP. Changing patterns of thalassemia worldwide. Ann N Y Acad Sci. 2005;1054:18-24.

33. Chinelato-Fernandes AR, Bonini-Domingos CR. Contribuição do estudo molecular de hemoglobinas S-like para o conhecimento da diversidade genética da população brasileira. Rev Bras Hematol Hemoter 2005; 27(3):208-210.

Avaliação: Editor e dois revisores externos

Conflito de interesse: não declarado

Recebido: 04/07/2007

Aceito: 18/01/2008 